\title{
IMPLEMENTATION OF NEW INTERNATIONAL STANDARDS FOR CERTIFICATION AND INSPECTION BODIES
}

\author{
Dr Predrag Popović* \\ Institute of nuclear sciences VINCA, Belgrade, Serbia \\ Dejana Popović \\ Institute of nuclear sciences VINCA, Belgrade, Serbia
}

The paper provides a general review of accreditation as an effective and efficient means for provision of competence, impartiality, independence and integrity of conformity assessing organizations, which creates confidence of all interested parties into the results of testing, inspection and certification of products processes and services. Implementation of international standards, as the accreditation proceedings brought into accord, provides similar levels of competence of conformity assessing bodies in all states and obtaining comparable results, thus contributing, within different international and regional agreements, to the possibility of creating mutual recognition of conformity documents - i.e. reports and certificates. New requirements are presented brought about by the new standards of SRPS ISO/IEC 17065:2013 and SRPS ISO/IEC 17020:2012, as well as their application in the certification and inspection body Vinca Institute.

Key words: Accreditation, Standards, Certification, Inspection, Management of impartiality

\section{INTRODUCTION}

The precondition for trading under uniform conditions is that every product, officially accepted in one country, also becomes accepted in the markets of other states, without repeated testing, inspection and certification. It is therefore requested that product conformity with the established requirements is determined objectively, and this objective determining can be done by the conformity assessment bodies (TOU). The conformity assessment bodies perform the activities of conformity assessment covering certification, inspection, testing and calibration. The basic task of conformity assessment is to create confidence with all interested parties that the product/process/service fulfills the determined/ prescribed requirements. It is important for all the stakeholders (state, manufacturer, product user) that such bodies are competent for performing their tasks. For this reason, a system has been established of impartial competence verification of conformity assessment bodies. This verification is performed by competent accreditation bodies that are impartial with respect to both TOU and to their clients, mostly operating on non-profit basis. Conformity assessment is performed by accredited organizations.
Accreditation represents the official acknowledgement by which the national accreditation body confirms that an organization fulfills the established requirements and that it is competent for performing the tasks of conformity assessment. Development of the accreditation process has been accelerated by establishing of the European Union's common market and by developing a general audit approach through a "third party", where all conformity assessment processes are conducted by competent organizations which are independent from manufacturers and buyers [03, 08].

Application of international standards, as the conforming accreditation processes, enables similar competence levels of conformity assessment bodies in all countries and obtaining of comparable results, thus contributing, within different international and regional treaties, to mutual recognition of conformity documents - reports and certificates. ISO - the International Organization for Standardization and IEC - International Electro technical Commission constitute a specialized system for standardization worldwide. National bodies which are the members of ISO or IEC participate in the work on developing international standards through technical committees set up by ISO and IEC individually to deal with certain field of technical activities. ISO and IEC 
Technical committees cooperate in the areas of mutual interest. The work on developing international standards and instructions in the field of conformity assessment is the responsibility of the ISO's Committee on Conformity Assessment (CASCO). In order to have a standard published as an international one, the votes of at least $75 \%$ national bodies for standardization participating in the voting are required. The Committee for Conformity Assessment has created numerous international standards and guidelines covering the following fields: principles and terminology, common elements, conformity assessment practice code, composing specific requirements, testing, inspection, suppliers' conformity declarations, certification, products, management systems, expert persons, accreditation, peer assessment and mutual recognition.

New versions of the standards for products and processes certification and inspection bodies have appeared relatively recently, and the ATS has just started accreditation of the conformity assessment bodies in accordance with the new standard versions' requirements.

The paper gives a general outline to accreditation as the effective and efficient means for providing competence, impartiality, independence and integrity of the conformity assessing organizations, which creates confidence of all interested parties in the results of testing, inspection and certification of products, processes and services [02]. New requirements have been presented, brought by the new versions of SRPS ISO/IEC 17065:2013 and SRPS ISO/IEC 17020:2012 standards, as well as the differences with respect to the previous standards versions. An abbreviated presentation is given of the new standard versions in the Certification and Inspection Body for products of Vinča Institute, with the focus on the standards' key requirements.

\section{CONFORMITY ASSESSMENT OF PRODUCTS AND SERVICES}

Organizations performing conformance assessment of products and services are to fulfill the requirements and to be accredited in accordance with the following Serbian, i.e. taken over European and international standards:

- Products certification is performed by the certification bodies which fulfill the requirements of the standard SRPS ISO/IEC 17065:2013 Conformity assessment - Requirements for bodies certifying products, processes and services [05].

- Products inspection is done by the Inspection Bodies fulfilling the requirements of the standard SRPS ISO/IEC 17020:2012 Conformity assessment - Requirements for the operation of various types of bodies performing inspection [06].

- Testing of products is done by the Testing Laboratories which fulfill the requirements of the standard SRPS ISO/IEC 17025:2006 General requirements for the competence of testing and calibration laboratories [07].

Certification of products or services is the way to acquire safety, i.e. to obtain guarantee that the product/service has been in conformity with the established standards or with other normative documents. Within the field of mandatory certification, state bodies apply the laws covering approvals of products and services with respect to safety, health and environment protection, prevention of fraud or non-allowed market behavior. In the domain of voluntary certification, many industrial branches have established both within one industry and globally, the systems of conformity assessment and approval, with the aim of reaching one minimal technical level, enabling comparability, as well as providing competition under equal conditions.

Certification of products, processes and services should enhance confidence to all the interested parties and offer proof on conformity, so that manufacturers or service providers can place their goods/services in the market more effectively. The basic purpose of products/services certification is as follows:

- To meet the needs of consumers, clients, i.e. of all interested parties, instilling confidence in fulfillment of their requirements,

- To provide suppliers of products/services with the proof on conformity for the market, obtained from the "third"-independent party.

Certification of products, processes or services is as worth as is the degree of confidence and the extent to which we can rely to the statements of impartial and competent third party, asserting that the specified requirements have been satisfied. The international standard SRPS ISO/IEC 17065:2013 [05] for certification bodies specifies requirements the application of which enables certification system management through the "third party", in a consistent and reliable way, as well as facilitating recognition of the certification results on national and international levels [02]. 
The result of products and services certification process is the statement of conformity for products and services to relevant standards and other normative documents, provided in the form of Conformity Certificate or Mark. According to [05], the client is an organization or person accountable to the certification body to ensure that certification requirements have been met, including the requirements for the product. In addition, the term client in the standard implies the applicant as well. Products inspection is conducted by inspection bodies performing conformity assessment of products, processes and services for clients, for their own organizations and/or for official administration bodies, so as to provide information to the interested parties relating to conformity to regulations, standards or specifications. Inspection parameters can cover: quantity, quality, safety, suitability for use and maintaining of permanent operational safety of facilities or systems.

The international standard SRPS ISO/IEC 17020:2012 [06] for the bodies performing inspection is based on the experiences of European inspection bodies. It covers the activities of testing materials, products, installations, facilities, processes, work procedures or services, as well as determining their conformity to the requirements and then issuing Reports/Certificates on Inspection to users, and also to the state administration surveillance bodies if so required [02].

Inspection of a product, an installation or facility can cover all phases of their life, including the phase of designing as well. Such activity usually requires expert evaluation in rendering a service, especially when conformity assessment is at stake. This international standard is also intended to be used as support to introducing conformity assessment procedures, referring to modules for various phases of conformity assessment procedures in the directives based on the EU New and Global Approach.

\section{REQUIREMENTS OF NEW INTERNATIONAL STANDARDS FOR CERTIFICATION AND INSPECTION BODIES}

The new issue of the international standard for certification bodies certifying products was published by the Institute for Standardization of Serbia on March 20 th , 2013: the standard SRPS ISO/IEC 17065:2013 Conformity assessment - Requirements for the bodies certifying products, processes and services. In this international standard, the term product can imply a process or service, except in cases when it is asserted by specific provi- sions that it refers to processes or services. The standard SRPS ISO/IEC Guide 65:1999 (SRPS EN 45011:2004) is withdrawn and replaced by this standard. After 15.09.2015., all awarded accreditations according to standard SRPS EN 45011:2004 cease to be valid. The requirements of standard SRPS EN 45011:2004 General requirements for the organizations conducting certification systems have been structured through 12 chapters with the total of 23 items of requirements. However, the requirements of standard SRPS ISO/IEC 17065:2013 Conformity assessment - Requirements for the bodies certifying products, processes and services have been structured into 5 chapters of the requirements, i.e. with the total of 31 items of the requirements, as follows:

1. General requirements (6 items)

2. Structural requirements (2 items)

3. Resource requirements ( 2 items)

4. Process related requirements (13 items)

5. Management requirements (8 items)

The new international standard edition for the inspection bodies inspecting products was published by the Institute for Standardization of Serbia on May 23rd, 2012 - the standard SRPS ISO/IEC 17020:2012 Conformity assessment Requirements for the operation of various types of bodies performing inspection. The standard SRPS ISO/IEC 17020:2002 is withdrawn and replaced by this standard. After 01.03.2015, all awarded accreditations according to SRPS ISO/IEC 17020:2002 cease to be valid. The requirements of the standard SRPS ISO/IEC 17020:2002 General criteria for the operation of various types of bodies performing inspection have been structured through 14 chapters with the total of 70 items of the requirements. However, the requirements of standard SRPS ISO/ IEC 17020:2012 Conformity assessment - Requirements for the operation of various types of bodies performing inspection have been structured into 5 chapters of requirements, i.e. the total of 21 items of requirements, as follows:

1. General requirements ( 2 items)

2. Structural requirements (2 items)

3. Resource requirements ( 2 items)

4. Process requirements ( 6 items)

5. Management system requirements ( 8 items) The difference between the old and new versions of the standards is obvious both regarding structure and 
regarding number of items of requirements, primarily in the clear and precise defining of the requirements. There is also a visible coordination in bringing and composing of the new standard versions, as well as equalization of the structure, i.e. of the requirement chapters and items of both standards.

Accreditation will be suspended and/or revoked to the accredited certification and inspection bodies which do not manage to adjust themselves to the new relevant standard issue until the stated periods of time.

In connection with product certification, and as compared to the instructions in SRPS ISO/IEC Guide 65:1996, i.e. to the standard SRPS EN 45011, the standard SRPS ISO/IEC 17065:2013 brings about the following significant changes [09]:

- restructuring of the standards based on the joint structure accepted by ISO (The International Organization for Standardization)/CAS$\mathrm{CO}$ (Committee on Conformity Assessment);

- modifications based on standards ISO/PAS 17001 (impartiality), ISO/PAS 17002 (confidentiality), ISO/PAS 17003 (appeals and complaints), ISO/PAS 17004 (information disclosure) and ISO/PAS 17005 (management system organization);

- introducing functional approach from ISO/IEC 17000 into the process requirements in item 7;

- information on implementing of standards for processes and services into Annex B,

- revision of terms and definitions, item 3;

- improving the impartiality requirements (the mechanism);

- consolidation of the management system requirements, item 8;

- Involvement of the principles for certification bodies certifying products, and their activities, into Annex A;

- improvement by taking into consideration the document IAF GD 5;

- involvement of referrals to certification schemes, where the certification scheme implies the certification system which refers to specified products to which the same specified requirements and specific rules and procedures apply, while the general guidelines for schemes development are given in ISO/IEC 17067.

A certification body is the body for conformity assessment which carries out the certification scheme as the third party.
In connection with products inspection, the new version of the standard SRPS ISO/IEC 17020:2012 involves changes/modifications which are contained in the following requirements [09]:

- identification of the risk to impartiality of an inspection body and elimination or minimizing the risk to impartiality;

- legally taking over of the information management obligations in the inspection body informing the client in advance of information that will be publicly available;

- adequate insurances or reserves;

- availability of one or more persons in the role of technical managers;

- documented procedures for selection, training, official authorization and monitoring of inspectors and other personnel involved in the inspection activities;

- monitoring performances of all inspectors and other staff - the results of monitoring their work are taken into consideration in planning the trainings;

- Informing the client if the inspection method which the client proposed is not adequate;

- internal traceability of reports/certificates on inspection, all the way to the inspectors who performed inspection;

- the mandatory elements presented in the report/certificate on inspection - the statement on conformity is a mandatory element only when it is applicable;

- the process with complaints and appeals (stipulated process minimal elements and methods, requirements for reporting on progress and results);

- options A and B for organizing the management system.

\section{IMPLEMENTING OF NEW VERSIONS OF STANDARDS FOR CERTIFICATION AND INSPECTION BODIES}

New versions of the both international standards have got fully modified structure with respect to previous versions of the standards. They also contain some fully novel requirements, while the existing requirements have greatly been revised and appended. Bearing all this in mind, it has been determined that it is necessary to perform a complete reengineering of the existing documentation of the Inspection Body for the products of Vinča Institute [03]. This primarily refers to composing of a new procedure regarding impartiality and independence, as well as to 
composing a new Quality Manual version. With the aim of fulfilling the requirements of the new standard versions in the Certification and Inspection Bodies of Vinča Institute, first of all, they have been analyzed with respect to previous versions, and then modifications to be realized have been identified and the plan has been defined for implementing the transfer to the new standards issues as well as conducting of complete documentation reengineering.

Implementation of the new standards versions in the Certification and Inspection Bodies for products requires performing necessary changes and improvements, which have covered the following documents:

- Statement on quality policy,

- Quality Manual,

- Procedure and records regarding impartiality, independence and confidentiality,

- All existing procedures, instructions and records with the aim of conforming to new/ changed standards requirements.

In transferring to/adjusting to new standards versions for certification and inspection bodies primarily for products and services, the Quality Manual as the supreme document in the documentation pyramid in the certification and inspection bodes, has to be fully formed according to chapters and items of the new standards versions' requirements. Many amendments have been implemented through adequate procedures, instructions and records. Table 1, stating the requirements of standard SRPS ISO/IEC 17065 for certification bodies, is provided with the aim of enabling better perception and envisaging the scope of changes, with the notes on whether the requirement is new or modified and amended with respect to previous standard/version, and the manner of implementation into the documentation of the Certification Body for products. Figure 1. presents the certification scheme, which includes the activities of the Certification Bureau of Vinca Institute [03, 04].

The same approach has been used in adjusting the documentation of the Inspection Body for products, in accordance with the new standards requirements.

\section{MANAGEMENT OF IMPARTIALITY}

The greatest changes in the new standard versions for certification and inspection bodies refer to the requirements for safeguarding impartiality, from the point of view of:

- identification of risk to impartiality;

- impartiality with respect to other parts of the same legal entity and of the entity under the organizational control;

- Impartiality with respect to separate legal entities;

- Precluding the influence of organizations or personnel rendering consulting services.

Impartiality implies presence of objectivity, i.e. the absence of conflict of interest or the fact that it has been resolved to the extent that it cannot have detrimental effect on the certification/inspection body's activities. The terms that are useful in conveying the elements of impartiality are: absence of favoritism, independence, neutrality, fairness, even-handedness, detachment and similar.

Certification Body or Inspection Body for products has to be responsible for impartiality of its certification/inspection activities and may not allow commercial, financial, political or other pressures to exert influence to compromise impartiality, while the very mechanism for providing impartiality has to be officially documented.

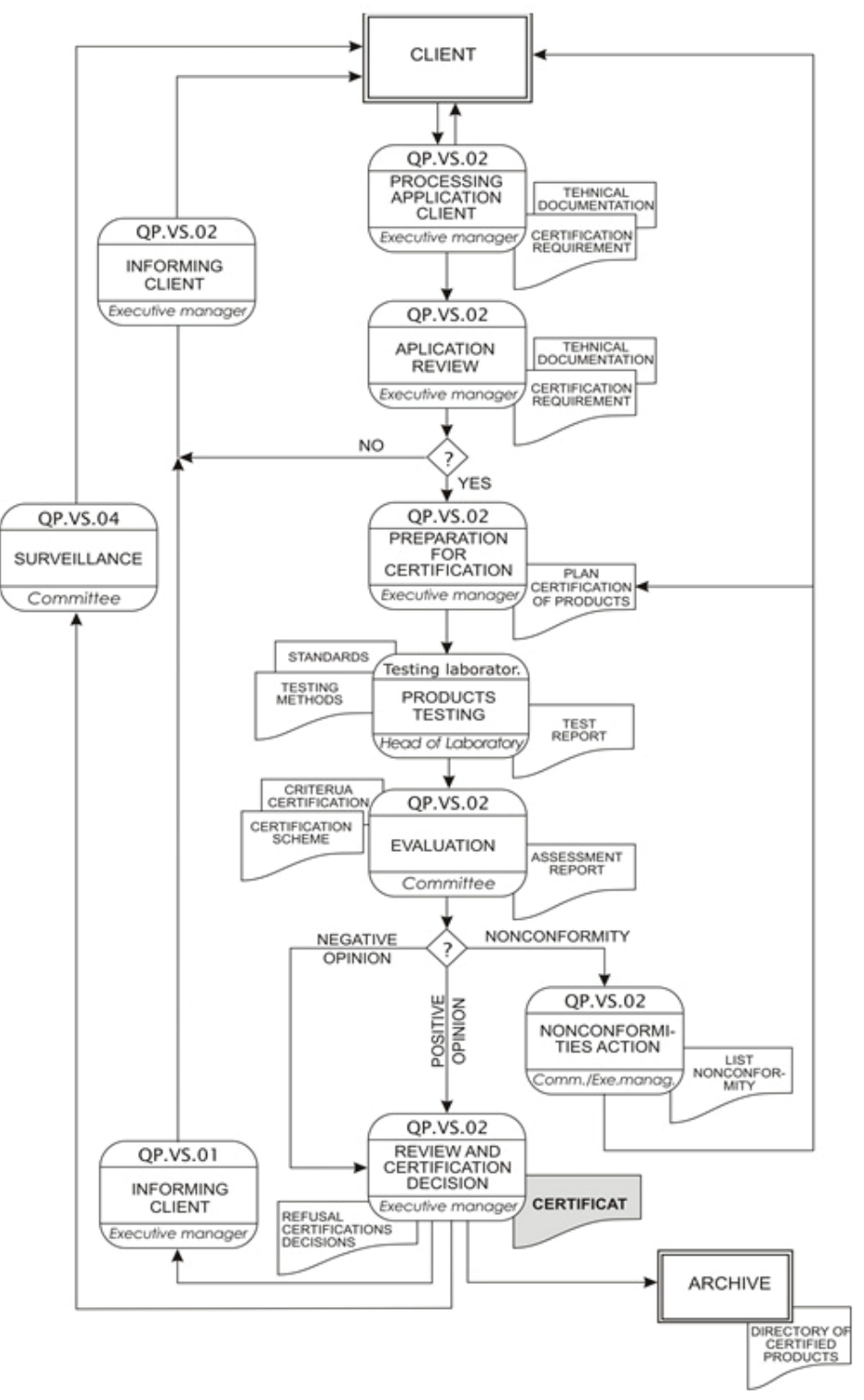

Figure 1: Certification Scheme 
Table 1: Requirements of the standard and adequate documentation which fulfills the requirements for the certification body for products - the Certification Bureau

\begin{tabular}{|c|c|c|}
\hline $\begin{array}{l}\text { REQUIREMENT (item) of the } \\
\text { STANDARD SRPS ISO/IEC 17065:2013. }\end{array}$ & $\begin{array}{l}\text { Requirement with respect to } \\
\text { previous standard }\end{array}$ & $\begin{array}{l}\text { Manual, procedures, } \\
\text { guidelines and adequate } \\
\text { records }\end{array}$ \\
\hline \multicolumn{3}{|l|}{ 4. GENERAL REQUIEMENTS } \\
\hline 4.1. Legal and contractual matters & Changed/amended & (QM.VS.01) Quality Manual \\
\hline 4.1.1. Legal responsibility & Changed/amended & (QM.VS.01) Quality Manual \\
\hline \multirow{2}{*}{ 4.1.2. Certification agreement } & \multirow{2}{*}{ New requirement } & $\begin{array}{l}\text { (QZ.VS.18) Certification } \\
\text { agreement }\end{array}$ \\
\hline & & $\begin{array}{l}\text { (QP.VS.02) Certification } \\
\text { procedure }\end{array}$ \\
\hline \multirow{2}{*}{ 4.3. Liability and financing } & \multirow{2}{*}{ Changed/amended } & $\begin{array}{l}\text { (QP.VS.12) Financing of } \\
\text { certification body activities }\end{array}$ \\
\hline & & $\begin{array}{l}\text { (QU.VS.08) Manual on } \\
\text { certification body operation }\end{array}$ \\
\hline 4.4. Non-discriminatory conditions & New requirement & $\begin{array}{l}\text { (QP.VS.01) Informing of } \\
\text { services user }\end{array}$ \\
\hline 4.5. Confidentiality & Changed/amended & $\begin{array}{l}\text { (QU.VS.08) Manual on } \\
\text { certification body operation }\end{array}$ \\
\hline 4.6. Publicly available information & Changed/amended & $\begin{array}{l}\text { (QP.VS.01) Informing of } \\
\text { services user (www.vinca.rs) }\end{array}$ \\
\hline \multicolumn{3}{|l|}{ 5. STRUCTURAL REQUIREMENTS } \\
\hline 5.1. Organizational structure and top management & Changed/amended & (QM.VS.01) Quality Manual \\
\hline \multirow{2}{*}{ 5.2. Mechanism for safeguarding impartiality } & \multirow{2}{*}{ New requirement } & $\begin{array}{l}\text { (QP.VS.13) Impartiality } \\
\text { management }\end{array}$ \\
\hline & & $\begin{array}{l}\text { (QZ.VS.20) Contract with } \\
\text { certification personnel }\end{array}$ \\
\hline \multicolumn{3}{|l|}{ 6. RESOURCE REQUIREMENTS } \\
\hline 6.1. Certification body personnel & Changed/amended & (QM.VS.01) Quality Manual \\
\hline \multirow[t]{2}{*}{ 6.1.1. General } & \multirow[t]{2}{*}{ Changed/amended } & $\begin{array}{l}\text { (QP.VS.06) Management } \\
\text { of personnel competence }\end{array}$ \\
\hline & & (QZ.VS.06) Personnel card \\
\hline \multirow{4}{*}{$\begin{array}{l}\text { 6.1.2. Management of competence for per- } \\
\text { sonnel involved in the certification process }\end{array}$} & \multirow{4}{*}{ Changed/amended } & $\begin{array}{l}\text { (QP.VS.06) Management } \\
\text { of personnel competence }\end{array}$ \\
\hline & & $\begin{array}{l}\text { (QZ.VS.17) Personnel } \\
\text { competence assessment }\end{array}$ \\
\hline & & Training plan (annual) \\
\hline & & (QZ.VS.07) Training plan \\
\hline \multirow{2}{*}{ 6.1.3. Contract with the personnel } & \multirow{2}{*}{ At request } & $\begin{array}{l}\text { (QZ.VS.20) Contract with } \\
\text { certification personnel }\end{array}$ \\
\hline & & $\begin{array}{l}\text { (QP.VS.13) Impartiality } \\
\text { management }\end{array}$ \\
\hline 6.2. Resources for evaluation & New requirement & (QM.VS.01) Quality Manual \\
\hline 6.2.1. Internal resources & New requirement & (QM.VS.01) Quality Manual \\
\hline \multirow{2}{*}{ 6.2.2. External resources (outsourcing) } & \multirow{2}{*}{ Changed/amended } & $\begin{array}{l}\text { (QP.VS.03) Subcontract- } \\
\text { ing of services }\end{array}$ \\
\hline & & $\begin{array}{l}\text { (QZ.VS.20) Contract with } \\
\text { certification personnel }\end{array}$ \\
\hline
\end{tabular}




\begin{tabular}{|c|c|c|}
\hline $\begin{array}{l}\text { REQUIREMENT (item) of the } \\
\text { STANDARD SRPS ISO/IEC 17065:2013. }\end{array}$ & $\begin{array}{l}\text { Requirement with respect to } \\
\text { previous standard }\end{array}$ & $\begin{array}{c}\text { Manual, procedures, } \\
\text { guidelines and adequate } \\
\text { records }\end{array}$ \\
\hline \multicolumn{3}{|l|}{ 7. PROCESS REQUIREMENTS } \\
\hline \multirow{8}{*}{ 7.1. General } & \multirow{8}{*}{ Changed/amended } & $\begin{array}{l}\text { (QP.VS.02) Certification } \\
\text { procedure }\end{array}$ \\
\hline & & $\begin{array}{l}\text { (QU.VS.01) Products cer- } \\
\text { tification system }\end{array}$ \\
\hline & & $\begin{array}{l}\text { (QU.VS.02) Rules of certifi- } \\
\text { cation committee operation }\end{array}$ \\
\hline & & Decision on appointment \\
\hline & & $\begin{array}{l}\text { (QU.VS.03) Guidance for } \\
\text { certification of anti-explo- } \\
\text { sion safeguarded devices } \\
\text { intended tor the use in } \\
\text { spaces jeopardized by } \\
\text { explosive atmosphere }\end{array}$ \\
\hline & & $\begin{array}{l}\text { (QU.VS.04) Guidance for cer- } \\
\text { tification of home appliances }\end{array}$ \\
\hline & & $\begin{array}{l}\text { (QU.VS.05) Guidance for } \\
\text { certification of insulated } \\
\text { conductors and cables }\end{array}$ \\
\hline & & $\begin{array}{l}\text { Information on the procedure } \\
\text { available at www.vinca.rs }\end{array}$ \\
\hline \multirow{2}{*}{ 7.2. Application } & \multirow{2}{*}{ Changed/amended } & $\begin{array}{l}\text { (QZ.VS.01) Request for } \\
\text { product certification, avail- } \\
\text { able at www.vinca.rs }\end{array}$ \\
\hline & & $\begin{array}{l}\text { (QP.VS.02) Certification } \\
\text { procedure }\end{array}$ \\
\hline \multirow{4}{*}{ 7.3. Application review } & \multirow{4}{*}{ Changed/amended } & $\begin{array}{l}\text { Part of the Request for prod- } \\
\text { uct certification (QZ.VS.01) }\end{array}$ \\
\hline & & $\begin{array}{l}\text { Testing of products accord- } \\
\text { ing to Certification Plan, part } \\
\text { of the Request for product } \\
\text { certification (QZ.VS.01) }\end{array}$ \\
\hline & & $\begin{array}{l}\text { Testing report (laboratory } \\
\text { format) }\end{array}$ \\
\hline & & $\begin{array}{l}\text { (QP.VS.02) Certification } \\
\text { procedure }\end{array}$ \\
\hline \multirow{2}{*}{ 7.4. Evaluation } & \multirow{2}{*}{ Changed/amended } & $\begin{array}{l}\text { (QZ.VS.02) Report on as- } \\
\text { sessment }\end{array}$ \\
\hline & & $\begin{array}{l}\text { (QP.VS.02) Certification } \\
\text { procedure }\end{array}$ \\
\hline \multirow{3}{*}{ 7.5. Review } & \multirow{3}{*}{ Changed/amended } & $\begin{array}{l}\text { (QZ.VS.02) Report on as- } \\
\text { sessment }\end{array}$ \\
\hline & & $\begin{array}{l}\text { (QZ.VS.18) Certification } \\
\text { agreement with client }\end{array}$ \\
\hline & & $\begin{array}{l}\text { (QP.VS.02) Certification } \\
\text { procedure }\end{array}$ \\
\hline \multirow{4}{*}{ 7.6. Certification decision } & \multirow{4}{*}{ Changed/amended } & $\begin{array}{l}\text { (QZ.VS.02) Report on as- } \\
\text { sessment }\end{array}$ \\
\hline & & (QZ.VS.03) Certificate \\
\hline & & $\begin{array}{l}\text { Decision on refusing of } \\
\text { certificate granting }\end{array}$ \\
\hline & & $\begin{array}{l}\text { (QU.VS.09) Manual on } \\
\text { use of certificate and con- } \\
\text { formity marks, available at } \\
\text { www.vinca.rs }\end{array}$ \\
\hline
\end{tabular}




\begin{tabular}{|c|c|c|}
\hline $\begin{array}{l}\text { REQUIREMENT (item) of the } \\
\text { STANDARD SRPS ISO/IEC 17065:2013. }\end{array}$ & $\begin{array}{l}\text { Requirement with respect to } \\
\text { previous standard }\end{array}$ & $\begin{array}{l}\text { Manual, procedures, } \\
\text { guidelines and adequate } \\
\text { records }\end{array}$ \\
\hline \multirow{5}{*}{ 7.7. Certification documentation } & \multirow{5}{*}{ Changed/amended } & $\begin{array}{l}\text { (QZ.VS.02) Report on as- } \\
\text { sessment }\end{array}$ \\
\hline & & (QZ.VS.03) Certificate \\
\hline & & $\begin{array}{l}\text { Decision on refusing of } \\
\text { certificate granting }\end{array}$ \\
\hline & & $\begin{array}{l}\text { Directory of refused and } \\
\text { taken away certificates }\end{array}$ \\
\hline & & $\begin{array}{l}\text { (QU.VS.12) Designation of } \\
\text { certificates }\end{array}$ \\
\hline 7.8. Directory of certified products & Changed/amended & $\begin{array}{l}\text { (QP.VS.01) Informing of } \\
\text { services user - available at } \\
\text { www.vinca.rs. }\end{array}$ \\
\hline \multirow[t]{2}{*}{ 7.9. Surveillance } & \multirow[t]{2}{*}{ Changed/amended } & $\begin{array}{l}\text { (QP.VS.04) Grant, use and } \\
\text { surveillance of certificates }\end{array}$ \\
\hline & & List of products for surveillance \\
\hline \multirow{2}{*}{ 7.10. Changes affecting certification } & \multirow{2}{*}{ Changed/amended } & $\begin{array}{l}\text { (QP.VS.02) Certification } \\
\text { procedure }\end{array}$ \\
\hline & & $\begin{array}{l}\text { (QZ.VS.18) Certification } \\
\text { agreement }\end{array}$ \\
\hline \multirow{2}{*}{$\begin{array}{l}\text { 7.11. Termination, reduction, suspension or } \\
\text { withdrawal of certification }\end{array}$} & \multirow[b]{2}{*}{ Changed/amended } & $\begin{array}{l}\text { (QP.VS.04) Grant, use and } \\
\text { surveillance of certificates }\end{array}$ \\
\hline & & $\begin{array}{l}\text { Statuses of certificates in the } \\
\text { Directory of issued certificates, } \\
\text { available at www.vinca.rs }\end{array}$ \\
\hline \multirow{3}{*}{ 7.12. Records } & \multirow{3}{*}{ Changed/amended } & $\begin{array}{l}\text { (QP.VS.08) Management } \\
\text { of certification records }\end{array}$ \\
\hline & & $\begin{array}{l}\text { (QZ.VS.05) The qual- } \\
\text { ity system documents } \\
\text { list contains also the list } \\
\text { of formal and informal } \\
\text { records }\end{array}$ \\
\hline & & $\begin{array}{l}\text { Formal records listed in } \\
\text { the Directory of Records }\end{array}$ \\
\hline \multirow{3}{*}{ 7.13. Complaints and appeals } & \multirow{3}{*}{ Changed/amended } & $\begin{array}{l}\text { (QP.VS.05) Solving of us- } \\
\text { ers' appeals, complaints } \\
\text { and contestations }\end{array}$ \\
\hline & & $\begin{array}{l}\text { (QP.VS.08) Management } \\
\text { of certification records }\end{array}$ \\
\hline & & $\begin{array}{l}\text { ( QZ.VS.04) Minutes on } \\
\text { users' complaints, avail- } \\
\text { able at www.vinca.rs }\end{array}$ \\
\hline \multicolumn{3}{|l|}{ 8. MANAGEMENT SYSTEM REQUIREMENTS } \\
\hline 8.1. Option A & & $\begin{array}{l}\text { (QM.VS.01) Quality } \\
\text { Manual }\end{array}$ \\
\hline \multirow{2}{*}{$\begin{array}{l}\text { 8.2. General management system require- } \\
\text { ments }\end{array}$} & \multirow[t]{2}{*}{ Changed/amended } & $\begin{array}{l}\text { Statement on quality } \\
\text { policy }\end{array}$ \\
\hline & & Quality objectives \\
\hline \multirow{3}{*}{ 8.3. Control of documents } & \multirow{3}{*}{ Changed/amended } & $\begin{array}{l}\text { (QU.VS.10) Guidelines for } \\
\text { generating quality system } \\
\text { documents }\end{array}$ \\
\hline & & $\begin{array}{l}\text { (QP.VS.07) Management } \\
\text { of quality system docu- } \\
\text { mentation }\end{array}$ \\
\hline & & $\begin{array}{l}\text { (QZ.VS.05) List of quality } \\
\text { system documents }\end{array}$ \\
\hline
\end{tabular}




\begin{tabular}{|c|c|c|}
\hline $\begin{array}{l}\text { REQUIREMENT (item) of the } \\
\text { STANDARD SRPS ISO/IEC 17065:2013. }\end{array}$ & $\begin{array}{l}\text { Requirement with respect to } \\
\text { previous standard }\end{array}$ & $\begin{array}{l}\text { Manual, procedures, } \\
\text { guidelines and adequate } \\
\text { records }\end{array}$ \\
\hline 8.4. Control of records & Changed/amended & $\begin{array}{l}\text { (QP.VS.08) Management } \\
\text { of certification records }\end{array}$ \\
\hline \multirow{3}{*}{ 8.5. Management review } & \multirow{3}{*}{ Changed/amended } & $\begin{array}{l}\text { (QP.VS.11) Management } \\
\text { quality system review }\end{array}$ \\
\hline & & $\begin{array}{l}\text { (QZ.VS.11) Report on man- } \\
\text { agement quality review }\end{array}$ \\
\hline & & $\begin{array}{l}\text { (QZ.VS.15) Questionnaire } \\
\text { available at www.vinca.rs }\end{array}$ \\
\hline \multirow{5}{*}{ 8.6. Internal audits } & \multirow{5}{*}{ Changed/amended } & $\begin{array}{l}\text { (QP.VS.09) Quality system } \\
\text { internal audits }\end{array}$ \\
\hline & & $\begin{array}{l}\text { (QZ.VS.22) Plan of inter- } \\
\text { nal audits }\end{array}$ \\
\hline & & $\begin{array}{l}\text { (QZ.VS.21) Internal audit } \\
\text { program }\end{array}$ \\
\hline & & Check list \\
\hline & & $\begin{array}{l}\text { (QZ.VS.10) Internal audit } \\
\text { report }\end{array}$ \\
\hline \multirow{2}{*}{ 8.7. Corrective actions } & \multirow{2}{*}{ Changed/amended } & $\begin{array}{l}\text { (QP.VS.10) Corrective and } \\
\text { preventive actions }\end{array}$ \\
\hline & & $\begin{array}{l}\text { Records of corrective and } \\
\text { preventive actions }\end{array}$ \\
\hline \multirow{2}{*}{ 8.8. Preventive actions } & \multirow{2}{*}{ Changed/amended } & $\begin{array}{l}\text { (QP.VS.10) Corrective and } \\
\text { preventive actions }\end{array}$ \\
\hline & & $\begin{array}{l}\text { Records of corrective and } \\
\text { preventive actions }\end{array}$ \\
\hline
\end{tabular}

The main objective of the new documents Quality Manual, procedures, guidelines and records - is identification of risks to impartiality of the certification/inspection bodies and eliminating or minimizing the risk to impartiality.

Bearing in mind the entire requirement related to impartiality, the Certification Body and Inspection Body for the Vinča Institute's products $[01,04]$ have defined a specific procedure covering establishment of the following activities:

- The mechanism for preserving impartiality

- Identification of threats/risks to impartiality

- Aspects of the risk to impartiality

- Analysis of risk to impartiality

- Contract with the certification personnel

- Analysis of the Quality Policy with respect to impartiality

By establishing the Committee for Safeguarding Impartiality (KON), a sustainable mechanism has been set up for preserving its own impartiality. Composition of the Committee for Safeguarding Impartiality enables a balanced representation of all the stakeholders, so that neither internal nor external Certification/Inspection Body's personnel prevail. The tasks of the Committee for Safeguard- ing Impartiality have been defined through the Rule Book on the Committee for Safeguarding Impartiality Operation which is submitted to all the members. The risks and threats to impartiality are identified within the List of Impartiality Related Risks records which contains: risk description, risk existence/occurrence estimation, proposed measures for risks eliminating or keeping under control and assessing of the actions taken. The List of Impartiality Related Risks is analyzed within the annual management review, which involves all the threats/risks and their elements (estimations) regarding objective product certification/inspection process. On the occasion of performing the analysis, actions are defined for elimination or keeping under control of new risks, as well as taking possible additional actions, bearing in mind the assessment of the already conducted actions for the already recognized risks.

The personnel participating in the procedure of product certification or inspection must not be involved in designing, manufacturing, delivery, installation, buying, ownership, use or maintenance of the products being certified. The Contract with the Certification Personnel is a document updated every year by all the associates-personnel of the products Certification or Inspection Bodies, by way of which the personnel: 
- commit themselves to fine-tune with the rules defined by the Certification/Inspection Body, including also those related to confidentiality and independence from commercial and other interests,

- out speaking/denouncing their previous and/or existing relationships that may affect impartiality.

All Contracts with the Certification Personnel are presented to the Committee for Safeguarding Impartiality within the impartiality analysis.

The Certification/Inspection Body for products has to have the top management devoted to impartiality, who affirm their commitment with respect to impartiality through the Quality Policy reviewed annually by the management.

\section{CONCLUSION}

Assessing of the accredited Certification and Inspection Bodies for products, processes and services by the Accreditation Body of Serbia, in the meaning of the transition i.e. adjusting/conforming to new standard versions for certification and inspection bodies, will be conducted in the course of regular surveillance assessments or reassessments, and at the latest in 2015.

In accordance with the ATS recommendation regarding transition to the new standard versions, the Vinča Institute's Inspection Body and Certification Body for products, have conducted detailed analyses of the standard requirements and then identified the changes to be realized, devised the implementation plan for transition to the new standard edition, conducting complete reengineering of the documentation of the Certification and Inspection Bodies for products. The complete design documentation of Vinča Institute's Certification and Inspection Bodies has been changed, which covered the following: Quality Manual, generating new procedures for impartiality management and accompanying records, as well as adjusting of the existing procedures, guidelines and records to the changed/amended standard requirements.

The reaccreditation of the Control Body for products in compliance with the new standard requirements was successfully performed at the beginning of this year and accreditation was granted by the Accreditation Body of Serbia (ATS). The design documentation, in accordance with the new standard requirements, for the Certification Body for products has been submitted to the ATS at the beginning of this year and the accreditation was granted by the Accreditation Body of Serbia. The design documentation according to the new standard requirements for the Certification Body for products was submitted to the ATS with the aim of conducting the assessment procedure.

\section{ACKNOWLEDGEMENT}

This paper has been realized within the TR 35031 project financed by the Ministry of Education, Sciences and Technological Development.

\section{REFERENCES}

1) Documentation accredited Certification Body for products and Inspection body for the products of the Institute of Nuclear Sciences Vinca, internally, (in Serbian) www.vinca.rs, (2013-2014), Belgrade

2) Popovic P., Mitrovic R.: (2009) „Product conformity assessment - infrastructure development", Institute of Nuclear Sciences Vinca, ISBN: 978-86-7306-098-9, Belgrade.

3) Popovic P., (2010) "Accreditation and conformity assessment”, University „Singidunum“, ISBN: 978-86-7912-289-6; Belgrade.

4) Popovic P., Popovic D.: (2014) „Management of Impartiality - A Key Request of New Version of International Standards for Certification and Inspection of Products and Services", SINTEZA - Singidunum University International Conference, DOI: 10.15308/SINTEZA-2014-887-892, CD Proceedings, pp 887-892, Belgrade.

5) Standard SRPS ISO/IEC 17065:2013 Conformity assessment - Requirements for bodies certifying products, processes and services, Institute for Standardization Serbia, Belgrade, 2013.

6) Standard SRPS ISO/IEC 17020:2012 Conformity assessment - Requirements for the operation of various types of bodies performing inspection, Institute for Standardization Serbia, Belgrade, 2012.

7) SRPS ISO/IEC 17025:2006 General requirements for the competence of testing and calibration laboratories, Institute for Standardization Serbia, Belgrade, 2006.

8) Stevanović, I., Stanojević, D., Nedić, A. (2013): „Setting the after sales process and quality control at car dealerships to the purpose of increasing clients' satisfaction", Journal of Applied Engineering Science (Istraživanja i projektovanja za privredu), No. 2, Vol. 11, pp. 81-88

9) www.ats.rs

Paper sent to revision: 28.07.2014.

Paper ready for publication: 10.09.2014. 